\title{
Effect of Atmosphere on Volatile Emission Characteristic in Oxy-Fuel Combustion
}

\author{
Le Wu, Shihe Chen, Jia Luo \\ Electric Power Research Institute of Guangdong Power Grid Corporation, Guangzhou, China \\ Email:wulecim@sina.com
}

Received December 6, 2012; revised January 10; 2013; accepted January 22, 2013

\begin{abstract}
A new type of power supply which was called oxy-fuel combustion power plant was introduced to reduce greenhouse gasses emission. In this paper the volatile emission characteristic of pulverized coal is studied under air atmosphere and oxy-fuel atmosphere. Combustion experiments of Datong bituminous coal were carried out in a wire mesh reactor at heating rates of $1 \mathrm{~K} / \mathrm{s}, 10 \mathrm{~K} / \mathrm{s}$ and $1000 \mathrm{~K} / \mathrm{s}$ respectively under air and $\mathrm{O}_{2} / \mathrm{CO}_{2}$ atmosphere conditions in order to investigate the volatile emission characteristic. The concentrations of volatile (mainly $\mathrm{CO}$ and $\mathrm{CH}_{4}$ ) emission were on-line measured by infrared gas analyzer. It was indicated that the concentrations of $\mathrm{CO}$ and $\mathrm{CH}_{4}$ in $\mathrm{O}_{2} / \mathrm{CO}_{2}$ atmosphere were higher than those in air. The direct oxidation of carbon and gasification reaction between carbon and $\mathrm{CO}_{2}$ are the main causes of the increased amount of $\mathrm{CO}$. The higher concentration of $\mathrm{CO}_{2}$ also results in the increased amount of $\mathrm{CH}_{4}$ in $\mathrm{O}_{2} / \mathrm{CO}_{2}$ conditions.
\end{abstract}

Keywords: Oxy-Fuel Combustion; $\mathrm{O}_{2} / \mathrm{CO}_{2}$ Atmosphere; Volatile Emission; Gasification Reaction

\section{Introduction}

The effect of greenhouse gasses on global climate change has resulted in the development of new technologies with lower emissions that can accommodate capture and sequestration of carbon dioxide [1,2], development of clean energy, smart grid and low-carbon economy has become a common choice for the world. Smart grid will penetrate new types of technologies into power supply side, power grid side and power consumer side to promote the carbon reduction in power systems through coordination of multiple technologies [3-5]. In this paper the specific technical path for a smart grid to achieve low-carbon power system are proposed based on clean production, a new type of power supply called oxy-fuel combustion power plant was introduced. Oxy-fuel combustion and $\mathrm{CO}_{2}$ capture from flue gases is a near-zero emission technology that can be adapted to both new and existing pulverized coal-fired power stations. It can produce a sequestration ready high- $\mathrm{CO}_{2}$-concentration effluent gas, and $\mathrm{CO}_{2}$ can be utilized in depleted oil and gas reservoirs to increase their production or storage in deep ocean and saline aquifers. Oxy-fuel combustion is less expensive for retrofitting existed plant than the other considered options [6$10]$.

CO production is an important reaction in the coal combustion process, $\mathrm{CO} / \mathrm{CO}_{2}$ product ratio is a major factor that influence the combustion temperature and re- leased energy, $\mathrm{CO} / \mathrm{CO}_{2}$ product ratio is also one of the basic research difficulties of coal combustion [11,12]. Carbon can be oxidized either to carbon monoxide or to carbon dioxide, the proportion to which carbon converts to either of the two products on the particle surface is still open to debate. $\mathrm{CH}_{4}$ emission characteristics have an important influence on pulverized coal ignition mechanism as the major component of volatile. Therefore, the generation of $\mathrm{CO}$ and $\mathrm{CH}_{4}$ has a major impact on combustion heat release and combustion reactions during pulverized coal combustion process [13].

Experimental and simulation studies have been carried out on CO production in the pulverized coal combustion process under air condition [14,15]. However, the reaction of carbon with oxygen is a continuous process, including heat, low temperature oxidation, ignition and combustion process. The measurement of $\mathrm{CO}$ is very difficult since carbon monoxide can be further oxidized in the reactor far from the burning particle. In addition, due to the limitations of the test conditions, previous studies were difficult to achieve precise control of particle heating rate, previous studies were also difficult to study $\mathrm{CO} / \mathrm{CH}_{4}$ formation characteristics under different heating rates.

The volatile emission characteristic of pulverized coal is very important for understanding how to switch existing burners from air to oxy-fuel combustion, The volatiles typically carry about $50 \%$ of the energy of the fuel, and in addition to heat release, the volatile oxidation is 
important for ignition. It is well studied under $\mathrm{O}_{2} / \mathrm{N}_{2}$ atmosphere, but under oxy-fuel atmosphere it haven't been recognized clearly $[16,17]$. In oxy-fuel combustion pulverized coal burns in $\mathrm{O}_{2} / \mathrm{CO}_{2}$ environment with higher $\mathrm{CO}_{2}$ concentration, instead of $\mathrm{O}_{2} / \mathrm{N}_{2}$ environment. Because of the high toxicity of $\mathrm{CO}$, it is very important to research whether $\mathrm{O}_{2} / \mathrm{CO}_{2}$ combustion lead to more $\mathrm{CO}$ emissions. Recently, $\mathrm{CO}$ emission characteristics under $\mathrm{O}_{2} / \mathrm{CO}_{2}$ combustion and conventional air combustion were studied by many scholars. Zheng et al. [18] did simulation study of $\mathrm{CO}$ production in $\mathrm{O}_{2} / \mathrm{CO}_{2}$ by FACT, but there is a lack of experimental verification. Wang [19] did combustion experiments using a $3 \mathrm{MW}$ level furnace in the same flame temperature under air and $\mathrm{O}_{2} / \mathrm{CO}_{2}$ atmosphere, the results showed that there is no great difference of CO content in the flame and flue gas, but modeling results suggested that the flame $\mathrm{CO}$ content increased 5 times in flame under $\mathrm{O}_{2} / \mathrm{CO}_{2}$ atmosphere. Woycenko et al. [20] did the experiments at a $2.5 \mathrm{MW}$ combustion furnace of IFRF found that CO content increased a lot in the flame zone, but the CO already burn out completely at the furnace exit, there is no observed significant $\mathrm{CO}$ emission. Because of the ignition delay and low peak temperature, when the oxygen content is reduced from $30 \%$ to $21 \%$, CO emissions increased from 34 ppmv to 200 ppmv. Glarborg et al. [21] did natural gas combustion experiments, the results showed that even if the excess oxygen exist, the high $\mathrm{CO}_{2}$ concentration in the $\mathrm{O}_{2} / \mathrm{CO}_{2}$ combustion at high temperatures can also prevent fuel (CO) was completely oxidized to $\mathrm{CO}_{2}$, its inhibitory effect is most obvious in the fuel-rich area.

The general experiments measured the total amount of the $\mathrm{CO}$ in the whole reaction process rather than the instantaneous value, therefore they can not reflect the actual CO formation regularities. Because of the presence of secondary reactions in pulverized coal combustion process, $\mathrm{CO}$ can be oxidized to $\mathrm{CO}_{2}$ on the surface of coal particles. It is very difficult to research the basis process of coal combustion in $\mathrm{O}_{2} / \mathrm{CO}_{2}$ atmosphere.

In this paper, the unique advantages of the wire mesh reactor were used. As was described in more details below [22], the wire-mesh reactor features a relatively accurate control of particle time-temperature history in the absence of significant secondary reactions of volatiles. The measurement of $\mathrm{CO}$ and $\mathrm{CH}_{4}$ formation characteristics during pulverized coal combustion can be very accurate in air and $\mathrm{O}_{2} / \mathrm{CO}_{2}$ combustion.

\section{Materials and Methods}

In our study Datong bituminous coal was used, the proximate and ultimate analyses were given in Table 1.

The details of the experimental process can be found in our recent work [22,23], the combustion experiments were carried out in a wire mesh reactor, $30 \mathrm{mg}$ coal sam-
Table 1. Properties of coal used.

\begin{tabular}{ll}
\hline & Datong \\
\hline Proximate analysis ${ }^{\mathrm{a}} \%$ (wt, dry) & \\
\hline VM & 26.7 \\
FC & 63.9 \\
A & 9.4 \\
\hline Ultimate analysis \% (wt, dry) & \\
\hline C & 71.94 \\
H & 4.37 \\
N & 0.79 \\
S & 0.35 \\
$\mathrm{O}^{\mathrm{b}}$ & 13.15 \\
\hline
\end{tabular}

${ }^{\mathrm{a}} \mathrm{VM}$, volatile matter; FC, fixed carbon; A, ash; ${ }^{\mathrm{b}}$ By difference.

ple was distributed between two layers of wire mesh. The wire mesh reactor was heated at a rate of $1 \mathrm{~K} / \mathrm{s}, 10 \mathrm{~K} / \mathrm{s}$, $1000 \mathrm{~K} / \mathrm{s}$ to $1273 \mathrm{~K} / \mathrm{s}$ separately, while a stream of air (or $21 \% \mathrm{O}_{2} / 79 \% \mathrm{CO}_{2}$ ) mixture continually passed through the mesh at $4.0 \mathrm{~L} / \mathrm{min}$ (measured under ambient conditions) to carry the evolved gas away. The concentrations of volatile (mainly $\mathrm{CO}$ and $\mathrm{CH}_{4}$ ) emission were on-line measured by infrared gas analyzer.

\section{Results and Discussion}

\subsection{Effects of Reaction Atmosphere on CO Emission Characteristics}

In this paper we studied $\mathrm{CO}$ emission characteristics of Datong bituminous coal in air and $\mathrm{O}_{2} / \mathrm{CO}_{2}$ atmosphere with a wire mesh reactor heated at a rate of $1 \mathrm{~K} / \mathrm{s}, 10 \mathrm{~K} / \mathrm{s}$, $1000 \mathrm{~K} / \mathrm{s}$ to $1273 \mathrm{~K} / \mathrm{s}$ separately, results are shown in Figures 1-3.

It can be seen that $\mathrm{CO}$ emission concentrations of Datong bituminous coal were higher in $\mathrm{O}_{2} / \mathrm{CO}_{2}$ atmosphere than in air atmosphere both under slow heating and fast heating rates. When the reactor was heated at a rate of 1 $\mathrm{K} / \mathrm{s}$, the highest concentration of $\mathrm{CO}$ in air atmosphere appeared at $863 \mathrm{~K}$, the highest value of $\mathrm{CO}$ concentration is $3270 \mathrm{ppm}$, in $\mathrm{O}_{2} / \mathrm{CO}_{2}$ atmosphere the highest value of $\mathrm{CO}$ concentration is $4045 \mathrm{ppm}$ as shown in Figure 1. In $\mathrm{O}_{2} / \mathrm{CO}_{2}$ atmosphere $\mathrm{CO}$ concentrations are generally higher than in traditional air atmosphere, the maximum value is about $23.7 \%$ higher. When heated at a rate of 10 $\mathrm{K} / \mathrm{s}$, the highest concentration of $\mathrm{CO}$ in air atmosphere appeared at $923 \mathrm{~K}$, the highest value of $\mathrm{CO}$ concentration is $2464 \mathrm{ppm}$, in $\mathrm{O}_{2} / \mathrm{CO}_{2}$ atmosphere the highest concentration of $\mathrm{CO}$ in air atmosphere appeared at $1073 \mathrm{~K}$, the highest value of CO concentration is $7842 \mathrm{ppm}$ which is 3.18 times than that in air atmosphere as shown in Figure 2. When heated at a rate of $1000 \mathrm{~K} / \mathrm{s}$, the highest value of $\mathrm{CO}$ concentration in air atmosphere is 957.4 ppm, in $\mathrm{O}_{2} / \mathrm{CO}_{2}$ atmosphere the highest value of $\mathrm{CO}$ concentration is $6023.1 \mathrm{ppm}$ which is 6.3 times than that in 


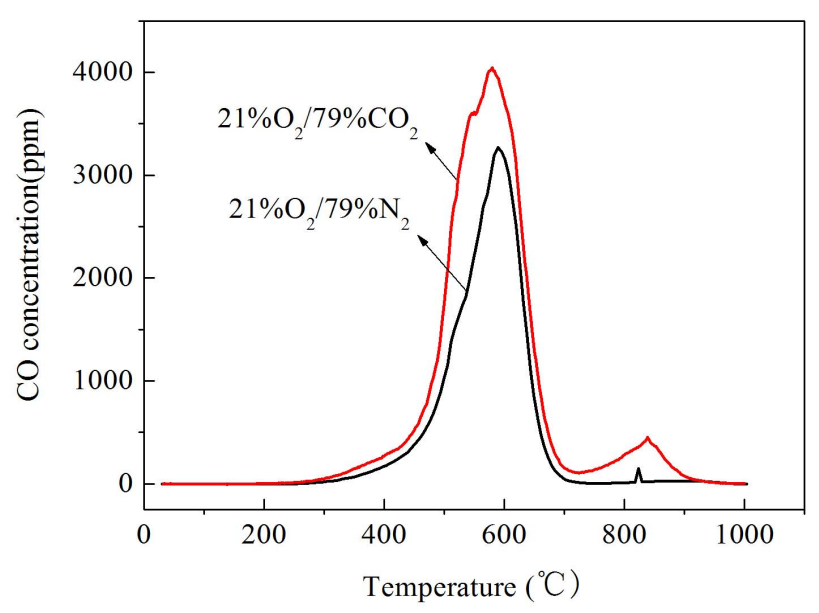

Figure 1. CO emission characteristics with a heating rate of $1 \mathrm{~K} / \mathrm{s}$.

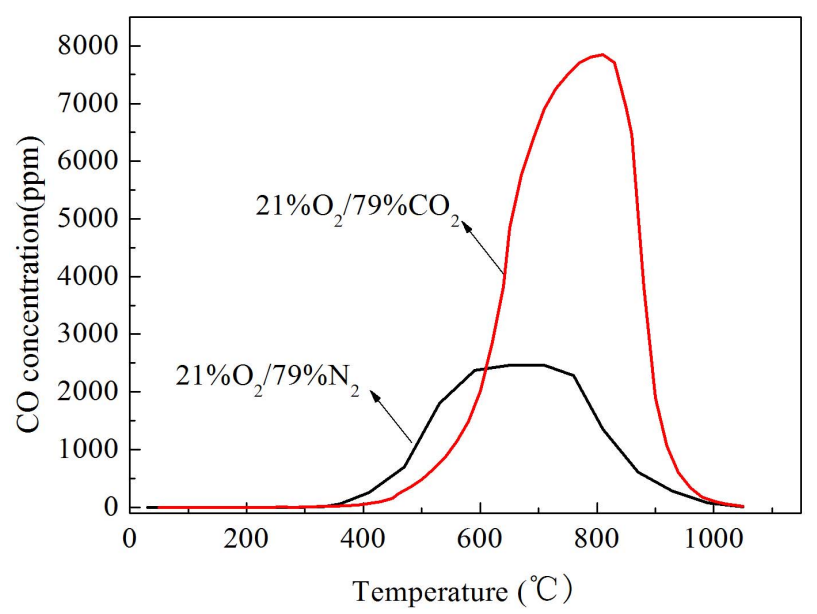

Figure 2. CO emission characteristics with a heating rate of $10 \mathrm{~K} / \mathrm{s}$.

air atmosphere as shown in Figure 3.

We found that when the coal was heated at a rate of 10 $\mathrm{K} / \mathrm{s}$, the ignition temperature of Datong bituminous coal is $855.99 \mathrm{~K}\left(\mathrm{~T}_{1}\right)$ in air atmosphere, the ignition temperature of Datong bituminous coal is $891.73 \mathrm{~K}\left(\mathrm{~T}_{2}\right)$ in $\mathrm{O}_{2} / \mathrm{CO}_{2}$ atmosphere. That means the temperature corresponds to the maximum $\mathrm{CO}$ concentration value is higher than the ignition temperature of pulverized coal, CO concentration continue to rise after coal ignition. In the low-temperature range, $\mathrm{CO}$ was produced from volatile emissions and direct oxidation of carbon, $\mathrm{CO}$ can be oxidized to $\mathrm{CO}_{2}$ in the presence of oxygen.

$\mathrm{CO}$ generate reactions are as follows:

1) Carbon direct oxidation to $\mathrm{CO}$ :

$$
\mathrm{C}+0.5 \mathrm{O}_{2} \rightleftarrows \mathrm{CO}
$$

2) Because of the existence of the high concentration $\mathrm{CO}_{2}$ gas in $\mathrm{O}_{2} / \mathrm{CO}_{2}$ atmosphere and the existence of partly high temperature area, carbon and $\mathrm{CO}_{2}$ gasification gen-

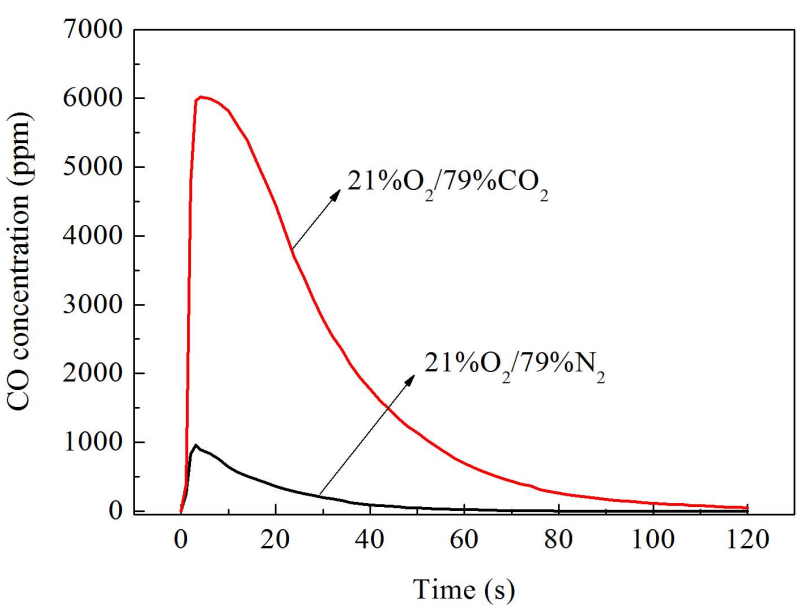

Figure 3. CO emission characteristics with a heating rate of $1000 \mathrm{~K} / \mathrm{s}$.

erates $\mathrm{CO}$

$$
\mathrm{C}+\mathrm{CO}_{2} \rightleftarrows 2 \mathrm{CO}
$$

3) The gasification reaction of carbon and water

$$
\mathrm{C}+\mathrm{H}_{2} \mathrm{O} \rightleftarrows \mathrm{CO}+\mathrm{H}_{2}
$$

4) The reaction of $\mathrm{CO}_{2}$ and $\mathrm{H}$ radical

$$
\mathrm{H}+\mathrm{CO}_{2} \rightleftarrows \mathrm{CO}+\mathrm{OH}
$$

$\mathrm{CO}_{2}$ is not inert but participates in chemical reactions, reactions of $\mathrm{CO}_{2}$ with free radicals may proceed at lower temperatures. The most important step is the reaction with atomic hydrogen (Equation (4)) which is comparatively fast even at medium temperatures. The reactions of $\mathrm{CO}_{2}$ with hydrocarbon radicals, will contribute to $\mathrm{CO}$ formation in the near-burner region under oxy-fuel combustion conditions. The higher levels of CO in this region may conceivably increase local problems with corrosion and slag, depending on the burner geometry and strategies for oxygen and flue gas. It would also be expected that the full oxidation of $\mathrm{CO}$ to $\mathrm{CO}_{2}$ would occur further downstream in the furnace compared to conventional combustion [24-26]. Reactions between $\mathrm{CO}_{2}$ and $\mathrm{CH}_{2}$ radicals may also attribute to the increase of $\mathrm{CO}$ content in the flame zone, but because of the less number of free radicals that reaction would not be expected to be the dominating reaction for the increasing of $\mathrm{CO}$ content.

In $\mathrm{O}_{2} / \mathrm{CO}_{2}$ combustion of coal the above reaction all exist, the thermal decomposition of $\mathrm{CO}_{2}$ is not the main reason for $\mathrm{CO}$ content increases in the flame. In $\mathrm{O}_{2} / \mathrm{CO}_{2}$ combustion due to the presence of high concentrations of $\mathrm{CO}_{2}$ and partial area with high temperature, gasification reaction between carbon and carbon dioxide generate $\mathrm{CO}$ is more likely to occur than air combustion. Therefore, the direct oxidation of carbon and gasification reaction between carbon and $\mathrm{CO}_{2}$ is the main reason for the increasing of $\mathrm{CO}$ content in oxy-fuel combustion. 


\subsection{Effects of Reaction Atmosphere on $\mathrm{CH}_{4}$ Emission Characteristics}

$\mathrm{CH}_{4}$ is an important component of the volatile during pulverized coal combustion and pyrolysis process, the $\mathrm{CH}_{4}$ emission characteristics is very important for understanding the combustion process of pulverized coal in air and $\mathrm{O}_{2} / \mathrm{CO}_{2}$ combustion. We studied $\mathrm{CH}_{4}$ emission characteristics of Datong bituminous coal in air and $\mathrm{O}_{2} / \mathrm{CO}_{2}$ atmosphere with a wire mesh reactor heated at a rate of 1 $\mathrm{K} / \mathrm{s}, 10 \mathrm{~K} / \mathrm{s}, 1000 \mathrm{~K} / \mathrm{s}$ to $1273 \mathrm{~K} / \mathrm{s}$ separately, results are shown in Figures 4-6.

It can be found that $\mathrm{CH}_{4}$ emission concentrations of Datong bituminous coal were higher in $\mathrm{O}_{2} / \mathrm{CO}_{2}$ atmosphere than in air atmosphere both under slow heating and fast heating rates. When the reactor was heated at rate of $1 \mathrm{~K} / \mathrm{s}$, the highest value of $\mathrm{CH}_{4}$ concentration is 75.6 ppm in air atmosphere, in $\mathrm{O}_{2} / \mathrm{CO}_{2}$ atmosphere the highest value of $\mathrm{CH}_{4}$ concentration is $107.19 \mathrm{ppm}$ as shown in Figure 4. In $\mathrm{O}_{2} / \mathrm{CO}_{2}$ atmosphere $\mathrm{CH}_{4}$ concentrations are generally higher than in traditional air atmosphere, the maximum value is about $41.8 \%$ higher. When the reactor was heated at rate of $10 \mathrm{~K} / \mathrm{s}$, the highest value of $\mathrm{CH}_{4}$ concentration is $1104 \mathrm{ppm}$ in air atmosphere, in $\mathrm{O}_{2} / \mathrm{CO}_{2}$ atmosphere the highest value of $\mathrm{CH}_{4}$ concentration is $1694 \mathrm{ppm}$ which is about $41.8 \%$ higher than that under air condition as shown in Figure 5. When heated at a rate of $1000 \mathrm{~K} / \mathrm{s}$, the highest value of $\mathrm{CH}_{4}$ concentration in air atmosphere is $318.7 \mathrm{ppm}$, in $\mathrm{O}_{2} / \mathrm{CO}_{2}$ atmosphere the highest value of $\mathrm{CH}_{4}$ concentration is $960.2 \mathrm{ppm}$ which is 3.01 times than that in air atmosphere as shown in Figure 6. So we can say that in $\mathrm{O}_{2} / \mathrm{CO}_{2}$ the $\mathrm{CH}_{4}$ emission concentrations were higher than that in air atmosphere.

Coal pyrolysis process is consist of some weak bonds breaking in macromolecules of coal at high temperature, then light gaseous substances, tar, etc release. The weakest depolymerization to generate small molecule chain occurred in early pyrolysis process, the occurrence of medium temperature cross-linking generating $\mathrm{CH}_{4}$. Another process in early pyrolysis is the functional group decomposition generating $\mathrm{CH}_{4}, \mathrm{CO}, \mathrm{H}_{2}$ and other gases. Reaction atmosphere affect coal pyrolysis process, atmosphere has an impact on pyrolysis products through secondary reactions. In $\mathrm{O}_{2} / \mathrm{CO}_{2}$ combustion, the presence of high concentrations of $\mathrm{CO}_{2}$ promotes the formation of $\mathrm{CH}_{4}$, therefore leading to the increase of $\mathrm{CH}_{4}$ concentration in oxy-fuel combustion.

\section{Conclusions}

Combustion experiments of Datong bituminous coal were carried out in a wire-mesh reactor at heating rates of 1 $\mathrm{K} / \mathrm{s}, 10 \mathrm{~K} / \mathrm{s}$ and $1000 \mathrm{~K} / \mathrm{s}$ respectively under air and $\mathrm{O}_{2} /$ $\mathrm{CO}_{2}$ atmosphere conditions. The concentrations of $\mathrm{CO}$ and $\mathrm{CH}_{4}$ emission from the coal were on-line measured

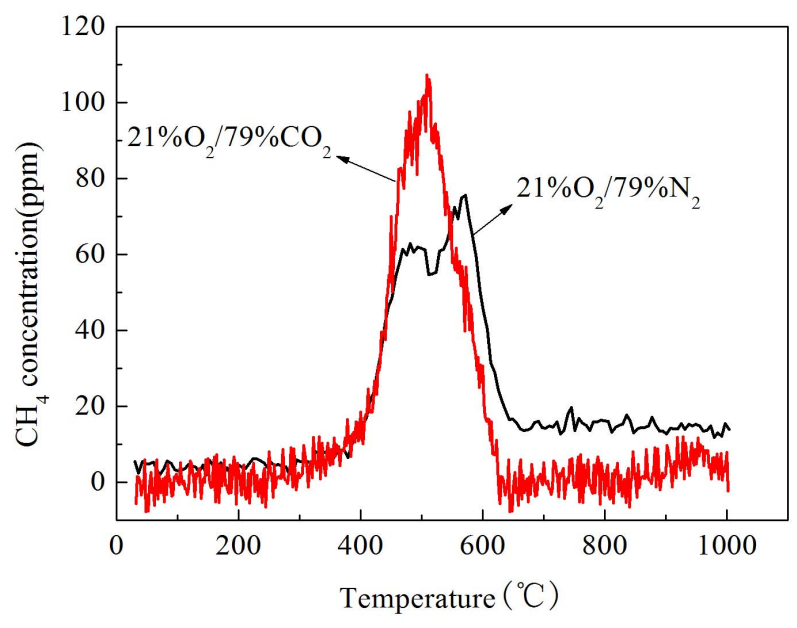

Figure 4. $\mathrm{CH}_{4}$ emission characteristics with a heating rate of $1 \mathrm{~K} / \mathrm{s}$.



Figure 5. $\mathrm{CH}_{4}$ emission characteristics with a heating rate of $10 \mathrm{~K} / \mathrm{s}$.

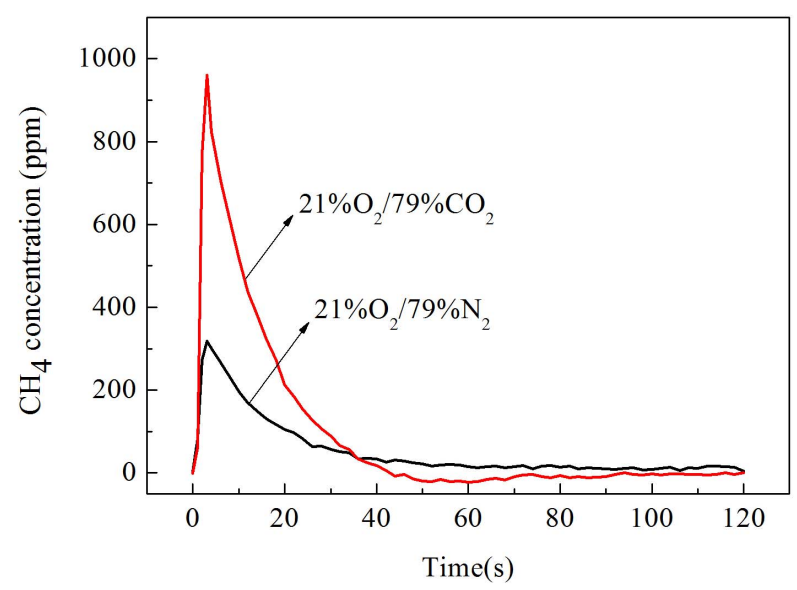

Figure 6. $\mathrm{CH}_{4}$ emission characteristics with a heating rate of $1000 \mathrm{~K} / \mathrm{s}$.

by infrared gas anlyzer. The following main conclusions can be drawn: 1) the concentrations of $\mathrm{CO}$ and $\mathrm{CH}_{4}$ in 
$\mathrm{O}_{2} / \mathrm{CO}_{2}$ atmosphere were higher than those in air. The direct oxidation of carbon and gasification reaction between carbon and $\mathrm{CO}_{2}$ are the main causes of the increased amount of $\mathrm{CO}$; 2) the higher concentration of $\mathrm{CO}_{2}$ also results in the increased amount of $\mathrm{CH}_{4}$ in $\mathrm{O}_{2}$ / $\mathrm{CO}_{2}$ conditions.

\section{REFERENCES}

[1] S. Gunter, A. M. Leema, S. Uwe and M. Jorg, "Oxy-Fuel Coal Combustion-A Review of the Current State of the Art," International Journal of Greenhouse Gas Control, Vol. 5, No. S1, 2011, pp. 16-35. doi:10.1016/j.ijggc.2011.05.020

[2] F. W. Terry, "Combustion Processes for Carbon Capture," Proceedings of the Combustion Institute, Vol. 31, No. 1, 2007, pp. 31-47. doi:10.1016/j.proci.2006.08.123

[3] Z. Liu, "Build Strong Smart Grid as Pillar of Sound and Rapid Development," Power System and Clean Energy, Vol. 25, No. 9, 2009, pp. 1-3. (in Chinese)

[4] EPRI, "Power Delivery System and Electricity Markets of the Future,” Palo Alto, CA, EPRI, 2003.

[5] M. Amin and P. F. Schewe, "Preventing Blackouts: Building a Smarter Power GRID,” Scientific American, 2008, pp. 60-67.

[6] B. T. Maja, B. Jacob, A. J. Peter, G. Peter, D. J. Anker, "Oxy-Fuel Combustion of Solid Fuels," Progress in Energy and Combustion Science, Vol. 36, No. 5, 2010, pp. 581-625. doi:10.1016/j.pecs.2010.02.001

[7] B. J. P. Buhre, L. K. Elliott, C. D. Sheng, R. P. Gupta and T. F. Wall, "Oxy-Fuel Combustion Technology for CoalFired Power Generation,” Progress in Energy and Combustion Science, Vol. 31, No. 4, 2005, pp. 283-307. doi:10.1016/j.pecs.2005.07.001

[8] D. Singh, E. Croiset, P. L. Douglas and M. A. Douglas, "Techno-Economic Study of $\mathrm{CO}_{2}$ Capture from an Existing Coal-Fired Power Plant: MEA Scrubbing vs $\mathrm{O}_{2} / \mathrm{CO}_{2}$ Recycle Combustion,” Energy Conversion and Management, Vol. 44, No. 19, 2003, pp. 3073-3091. doi:10.1016/S0196-8904(03)00040-2

[9] M. Alejandro and R. S. Christopher, "Ignition and Devolatilization of Pulverized Bituminous Coal Particles during Oxygen/Carbon Dioxide Coal Combustion," Proceedings of the Combustion Institute, Vol. 31, No. 2, 2007, pp. 1905-1912. doi:10.1016/j.proci.2006.08.102

[10] A. B. Paula and A. Yiannis, "Single-Coal-Particle Combustion in $\mathrm{O}_{2} / \mathrm{N}_{2}$ and $\mathrm{O}_{2} / \mathrm{CO}_{2}$ Environments," Combustion and Flame, Vol. 153, 2008, pp. 270-287.

[11] T. Zeng and W. Fu, "The Ratio $\mathrm{CO} / \mathrm{CO}_{2}$ of Oxidation on a Burning Carbon Surface,” Combustion and Flame, Vol. 107, No. 3, 1996, pp. 197-210. doi:10.1016/S0010-2180(96)00071-5

[12] M. Faraday and C. Lyell, "Explosions in Coal Mines," Philosophical Magazine, Vol. 26, 1845, pp. 16-35.

[13] K. Cen, Q. Yao and Z. Luo, “Advanced Combustion,” Zhejiang University Press, Hangzhou, 2002, pp. 277-284.
[14] J. Arthur, "Reactions between Carbon and Oxygen,” Transactions of the Faraday Society, Vol. 47, 1951, pp. 164-178. doi:10.1039/tf9514700164

[15] L. Tognotti, J. Longwell and A. Sarofim, “The Products of the High Temperature Oxidation of a Single Char Particle in an Electrodynamic Balance," Proceedings of the Combustion Institute, Vol. 23, No. 1, 1991, pp. 12071213.

[16] N. Kimura, K. Omata, T. Kiga, S. Takano and S. Shikisima, "Characteristics of Pulverized Coal Combustion in $\mathrm{O}_{2} / \mathrm{CO}_{2}$ Mixtures for $\mathrm{CO}_{2}$ Recovery,” Energy Conversion and Management, Vol. 36, No. 6-9, 1995, pp. 805-808. doi:10.1016/0196-8904(95)00126-X

[17] K. Renu, K. Liza and F.Terry, "Differences in Reactivity of Pulverised Coal in Air $\left(\mathrm{O}_{2} / \mathrm{N}_{2}\right)$ and Oxy-Fuel $\left(\mathrm{O}_{2} / \mathrm{CO}_{2}\right)$ Conditions," Fuel Processing Technology, Vol. 90, No. 6, 2009, pp. 797-802. doi:10.1016/j.fuproc.2009.02.009

[18] L. Zheng and E. Furimsky, "Assessment of Coal Combustion in $\mathrm{O}_{2} / \mathrm{CO}_{2}$ by Equilibrium Calculations," Fuel Processing Technology, Vol. 81, No. 1, 2003, pp. 23-34. doi:10.1016/S0378-3820(02)00250-3

[19] C. Wang, G. Berry and K. Chang, "Combustion of Pulverized Coal Using Waste Carbon Dioxide and Oxygen," Combustion and Flame, Vol. 72, No. 3, 1988, pp. 301310. doi:10.1016/0010-2180(88)90129-0

[20] D. Woycenko, K. Vande and P. Roberts, "Combustion of Pulverized Coal in a Mixture of Oxygen and Recycled Flue Gas,” European Commission Journal of Clean Coal Technology Program, Vol. 1, 1995, pp. 92-99.

[21] P. Glarborg and L. Bentzen, "Chemical Effects of a High $\mathrm{CO}_{2}$ Concentration in Oxy-Fuel Combustion of Methane,” Energy \& Fuels, Vol. 22, No. 1, 2008, pp. 291-296. doi:10.1021/ef7005854

[22] Y. Qiao, L. Zhang and E. Binner, “An Investigation of the Causes of the Difference in Coal Particle Ignition Temperature between Combustion in Air and in $\mathrm{O}_{2} / \mathrm{CO}_{2}$," Fuel, Vol. 89, No. 11, 2011, pp. 3381-3387. doi:10.1016/j.fuel.2010.05.037

[23] L. Wu, Y. Qiao, B. Gui and M. Xu, "Effects of Chemical Forms of Alkali and Alkaline Earth Metallic Species on the Char Ignition Temperature of a Loy Yang Coal under $\mathrm{O}_{2} / \mathrm{N}_{2}$ Atmosphere," Energy \& Fuels, Vol. 26, No. 1, 2012, pp. 112-117. doi:10.1021/ef2011386

[24] F. Liu, H. Guo and G. Smallwood, “The Chemical Effect of $\mathrm{CO}_{2}$ Replacement of $\mathrm{N}_{2}$ in Air on the Burning Velocity of $\mathrm{CH}_{4}$ and $\mathrm{H}_{2}$ Premixed Flames," Combustion \& Flame, Vol. 133, No. 4, 2003, pp. 495-497.

[25] F. Liu, H. Guo, G. Smallwood and O. Gulder, "The Chemical Effects of Carbon Dioxide as an Additive in an Ethylene Diffusion Flame: Implications for Soot and NOx Formation," Combustion \& Flame, Vol. 125, No. 1-2, 2001, pp. 778-787. doi:10.1016/S0010-2180(00)00241-8

[26] A. Masri, R. Dibble and R. Barlow, "Chemical Kinetic Effects in Nonpremixed Flames of $\mathrm{H}_{2} / \mathrm{CO}_{2}$ Fuel,” Combustion \& Flame, Vol. 91, No. 3-4, 1992, pp. 285-309. doi:10.1016/0010-2180(92)90059-X 